\title{
Validation of Modified Lowry for the Determination of Total Protein Concentration of Rhopalurus junceus Scorpion Venom
}

\author{
Arianna Yglesias-Rivera ${ }^{1 *}$, Ana Zenaida Viera-Morales ${ }^{1}$, Yania Suárez-Pérez² ${ }^{2}$ Jose Raúl Torres- \\ Viltres ${ }^{1}$ and Rayner Ochoa-Cardentey ${ }^{1}$ \\ ${ }^{1}$ Research Department, Laboratories of Biopharmaceuticals and Chemicals Productions (LABIOFAM), Havana, Cuba \\ ${ }^{2}$ Food and Pharmacy Institute, Havana University, Cuba
}

*Corresponding author: Arianna Yglesias-Rivera, Laboratories of Biopharmaceuticals and Chemicals Productions (LABIOFAM),

Ave. Independencia, Km 16 1⁄2, Santiago de Las Vegas, Boyeros, Havana, Cuba

ARTICLE INFO

Received: 㓞 June 08, 2020

Published: 幽 June 24, 2020

Citation: Arianna Yglesias-Rivera, Ana Zenaida Viera-Morales, Yania Suárez-Pérez, Jose Raúl Torres-Viltres, Rayner OchoaCardentey. Validation of Modified Lowry for the Determination of Total Protein Concentration of Rhopalurus junceus Scorpion Venom. Biomed J Sci \& Tech Res 28(3)-2020. BJSTR. MS.ID.004655.
ABSTRACT

Rhopalurus junceus scorpion venom is mainly composed by proteins and peptides. The determination of total protein has been determined by Lowry method. However, the reading has been performed in a spectrophotometer using quartz cuvettes. In the present study, we validate the modified Lowry method for the determination of total protein concentration of Rhopalurus junceus scorpion venom in microplates. The validated parameters were linearity, range, accuracy, repeatability, and intermediate precision. This method was specific for the quantification of total protein concentration of Rhopalurus junceus scorpion venom. The curve of modified Lowry was lineal in the evaluated range of $0.02-0.18 \mathrm{mg} / \mathrm{mL}\left(\mathrm{R}^{2}=0.998\right)$. The method was accurate with recovery percentage of $100 \pm 10 \%$ and possessed a good intra-day and interday precision based on relative standard deviation values (less than $4.3 \%$ and $9 \%$, respectively). The validation was satisfactory and the method of modified Lowry to microplates is considered valid for the quantification of total proteins in Rhopalurus junceus scorpion venom.

Keywords: Modified Lowry; Validation; Rhopalurus Junceus Scorpion Venom

\section{Introduction}

Scorpion venoms are a complex mixture of peptides and proteins with a broad range of biological activities, among which are peptides that impair proper functioning of ion-channels [1]. The molecules and peptides from the scorpion venom can be used to develop highly potent anticancer, antimicrobial and many other effective drugs [2]. Over the past few years, increasing number in vitro and in vivo studies with scorpion venom have been shown it capacity of the inhibition of cancer progression and induce apoptosis of tumor cells [3].

Rhopalurus junceus ( $R$. junceus) scorpion is an endemic species of Cuba that belongs to the Buthidae family and the venom from this scorpion has been used in traditional medicine as an anti-inflammatory, analgesic and antitumor drug [4]. Previous preclinical studies from our group have shown that R.junceus scorpion venom exerts a selective and cytotoxic effect against a panel of epithelial cancer cells without affecting normal cells [5]. Besides, this scorpion venom has been able to induce apoptosis on HeLa cervical-uterine cancer [5] and MDA-MB-231 metastatic breast cancer cell lines [6].

The validation is an important procedure in the pharmaceutical industry and is used to ensure that quality is built into the processes supporting drug development and manufacture [7]. Although many assays exist to determine total protein content in a variety of sample matrices, the first approach is the Lowry assay, which is based on formation of protein-copper complexes and subsequent reduction with Folin-Ciocalteu Reagent [8]. In our entrepreneurial group, the concentration of total proteins is determined by the Lowry method. In this conventional technique for measuring protein concentration, 
the reading is performed on a spectrophotometer using quartz cuvettes. This methodology presents as main practical limitations, the sample volumes necessary for performing the technique, especially when the quantity of sample to be analyzed is low and the reading time, when several samples are analyzed at the same time. Considering these restrictions, Herrera et al. [9], adapted this technique and performed the validation to use a 96-well microplate reader, which allows significantly reducing the volumes of the samples and the reagents used, increasing the number of samples to analyze and reduce reading time. For that reason, the objective of the present work was to validate the modified Lowry method to implement it in our quality control laboratories, particularly for the determination of the protein concentration of the $R$. junceus scorpion venom.

\section{Materials and Methods}

\section{Analytical Method}

The concentration of proteins present in $R$. junceus scorpion venom was determined through the method of modified Lowry [9]. Bovine Serum Albumin (BSA) was used as the reference standard.

\section{Validation Parameters}

The validation parameters selected are in correspondence with those defined in international guides such as the International Harmonization Conference (ICH) of 2005, the United States Pharmacopeia (USP) of 2017 (USP40) and regulation 41 of the CECMED of the year 2013 for methods of category I of content and potency of pharmaceutical products. Specificity, linearity, interval, accuracy, and precision were evaluated.

\section{Specificity}

For the specificity study we analyzed distilled water (placebo) and samples of Rhopalurus junceus scorpion venom. Absorbance values at $620 \mathrm{~nm}$ were determined and the absence of interferences verified in the analytic answer.

\section{Linearity and Interval of the System}

Six experiments were carried out in total, three independent experiments by two analysts and the corresponding calibration curves were constructed. The concentrations used of BSA were: $0.02,0.06,0.10,0.14$ and $0.18 \mathrm{mg} / \mathrm{mL}$; equivalent to $20,60,100$ 140 and $180 \%$. For each concentration level analyzes were done in triplicate. The results were processed by linear regression and the parameters were determined to assess the linearity of the system: linear regression coefficient $\left(\mathrm{R}^{2} \geq 0.98\right)$ and significance of the slope using the regression ANOVA ( $p \leq 0.01)(4)$. Other acceptance criteria used were line equation: $y=b x+a, r \geq 0.99$.

In addition, the Student's t-test was applied for evaluating if the experimental value (tcalc) and theorical value (tteo) are tcalc $\leq$ tteo for a $95 \%$ confidence. The response factors (f) were calculated according to the expression: $\mathrm{f}=\mathrm{y} / \mathrm{x}$, where $\mathrm{y}$ : analytical response, $\mathrm{x}$ : amount of analyte. The Relative Standard Deviation (RSD) of the Response Factors (RSDf) were determinate and the acceptance criteria established were RSDf $\leq 5 \%$ for a good linearity.

\section{Accuracy}

It was performed by evaluating the addition of BSA standard to the sample of $R$. junceus scorpion venom [10]. Samples of $R$. junceus scorpion venom was diluted 1:100, which it was prepared at a concentration such that its absorbance corresponded to the average interval of the calibration curve. Several mixtures were prepared by addition to the sample of $R$. junceus scorpion venom of different amounts of BSA, corresponding to the high ranges $(\mathrm{HR}=$ $0.16 \mathrm{mg} / \mathrm{mL}$ ), medium (MR $=0.08 \mathrm{mg} / \mathrm{mL}$ ) and low (LR= $0.04 \mathrm{mg} /$ $\mathrm{mL}$ ) of pattern curve of BSA. Three independent replicate were performed at each concentration level analyzed. The absorbance values obtained were subtracted from the absorbance value of albumin at the concentrations of $0.04,0.08$ and $0.16 \mathrm{mg} / \mathrm{mL}$ standard. The experimental concentration (Cexp) were compared with theoretic values (Ctheoretic). The recovery percentages ( $\%$ $\mathrm{R})$ of each preparation and the average value were analyzed, using the formula: $\mathrm{R}=\mathrm{A} / \mathrm{B}^{*} 100$, where $\mathrm{A}$ is Cexp and $\mathrm{B}$ is Ctheoretic (acceptance criteria: $R=100 \pm 10 \%$ ). The variability of the results was analyzed by calculating SD and RSD. In this case, RSD $\leq 10 \%$ of all recoveries obtained was considered as the criteria of acceptance for inter-day assay. Besides, the Cochran G test was performed to determine if the concentration factor could influence on the results. The experimental value of the Cochran G test (Gexp) was calculated by the following expression: $\mathrm{Gexp}=\mathrm{S}^{2} \max /\left(\mathrm{S}_{1}{ }_{1}+\mathrm{S}^{2}{ }_{2}+\mathrm{S}_{3}{ }_{3}\right)$. Gtab $(\alpha$ $=0.05 ; \mathrm{k}=3 ; \mathrm{n}=3$ ). Where $\mathrm{S}^{2} \max$ : maximum standard deviation, S1,2,3: deviation of level 1, 2 and 3. The k: experimental groups and n: determinations by group. If Gexp $<$ Gtab the variances of the three concentrations are equivalent, or what is the same, the concentration factor does not influence in the variability of the results.

\section{Precision}

The samples were tested at the high, medium and low intervals of the calibration curve, with six independent replicate. To assess repeatability (intra-day precision), it was performed under the same operating conditions: an analyst on the same day. The variability of the mean concentration, SD and RSD was determined at all intervals $(\mathrm{RSD} \leq 5 \%)$. For the study of intermediate precision (inter-day precision), the previous test was carried out, but during three different days and with the participation of two analysts, under different operating conditions and reagents, in the same laboratory. The variability of the results was determined by each analyst on different days through the RSD (RSD $\leq 10 \%$ ) [10].

\section{Results and Discussion}

The specificity of the method was demonstrated by the analysis of the blank matrix $\left(\mathrm{H}_{2} \mathrm{O}\right)$, which did not absorb at the working wavelength, so the method was specific for the quality control of 
R.junceus scorpion venom, taking into account that there are no other components involved in the prepared solutions. Through the statistical processing of the results of the linearity test it was shown that the system was linear in the studied concentration range $(0.02$, $0.06,0.10,0.14$ and $0.18 \mathrm{mg} / \mathrm{mL}$; equivalent to $20,60,100,140$ and $180 \%$, based on satisfactory fulfillment of all established criteria.
Each sample was analyzed three times. Good linearity was obtained (Figure 1). The relationship between the calibration curve and regression coefficient was: $\mathrm{A}=0.9896 \mathrm{C}+0.0015$ and correlation coefficient $\left(\mathrm{R}^{2}\right)$ was higher than 0.98 , indicating good linearity in the proposed range [10]. The statistical results of the calibration curves are presented in Table 1.

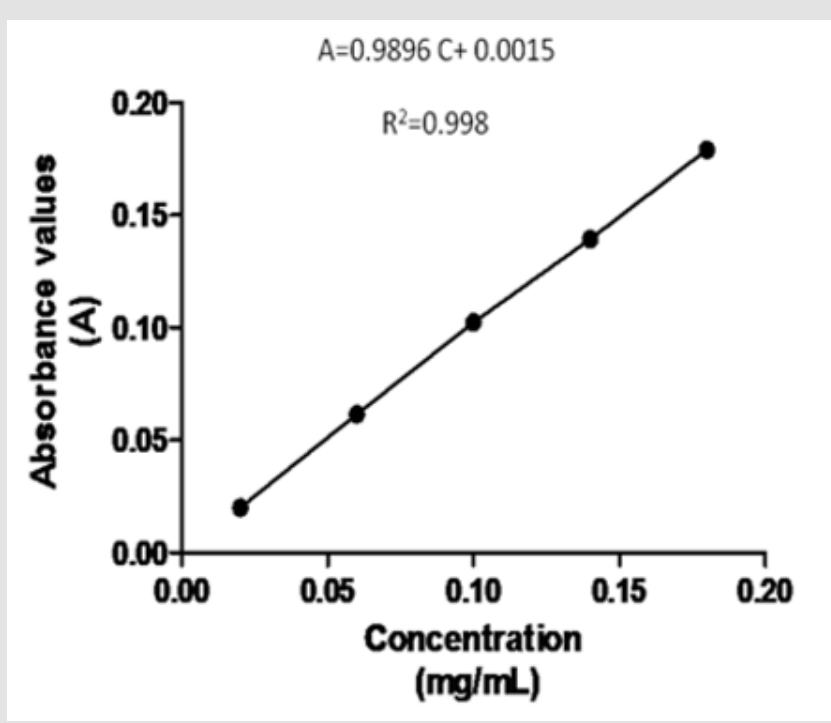

Figure 1: Calibration curve obtained with bovine serum albumin standard solutions using modified Lowry method.

Table 1: Statistical processing of linearity test of the system.

\begin{tabular}{|c|c|c|c|c|c|c|}
\hline \multirow{2}{*}{ Parameters } & \multicolumn{3}{|c|}{ Analyst-1 } & \multicolumn{3}{c|}{ Analyst-2 } \\
\cline { 2 - 6 } & Assay 1 & Assay 2 & Assay 3 & Assay 1 & Assay 2 & Assay 3 \\
\hline Equation of regression line & $\mathrm{y}=1,419 \mathrm{x}+0,091$ & $\mathrm{y}=1,588 \mathrm{x}+0,015$ & $\mathrm{y}=1,514 \mathrm{x}+0,015$ & $\mathrm{y}=1,059 \mathrm{x}+0,074$ & $\mathrm{y}=1,081 \mathrm{x}+0,063$ & $\mathrm{y}=1,172 \mathrm{x}+0,059$ \\
\hline $\begin{array}{c}\text { Correlation coefficient } \\
(\mathrm{r} \geq 0,99)\end{array}$ & 0,994 & 0,991 & 0,998 & 0,997 & 0,991 & 0,999 \\
\hline $\begin{array}{c}\text { Determination coefficient } \\
(\mathrm{r} 2 \geq 0,98)\end{array}$ & 0,988 & 0,983 & 0,996 & 0,995 & 0,981 & 0,998 \\
\hline $\begin{array}{c}\text { Relative standard deviation } \\
\text { (RSD ref } \leq 2 \%)\end{array}$ & 0,732 & 0,972 & 0,413 & 0,499 & 0,322 \\
\hline $\begin{array}{c}\text { RSD of response factors } \\
\text { (RSDf } \leq 5 \%)\end{array}$ & 3,478 & & 4,520 \\
\hline
\end{tabular}

The five points of the calibration curve showed accuracy within the specified parameters. For intra-test and inter-test accuracy, the acceptance criteria established were RSD $\leq 5 \%$ and RSD $\leq 10 \%$, respectively (Table 2). For accuracy, recovery percentages between $100 \pm 10 \%$ were obtained. All points of the curve accomplished the acceptance criteria established for the Student $t$ test, since the tcalc $\leq$ tteo for a $95 \%$ confidence [10]. The Table 3 shows the mean recoveries for three ranges (LR, MR and HR). The results were was $100 \pm 3 \%, 106 \pm 5 \%$ and $94 \pm 3 \%$ and the RSD was less than $5 \%$. In addition, all points of the curve met the acceptance criteria established for the Student's t-test, since the tcalc $\leq$ tteo for a $95 \%$ confidence. These results demonstrated the accomplished the acceptance criteria established for linearity, but now with 3 points (Figure 2). 


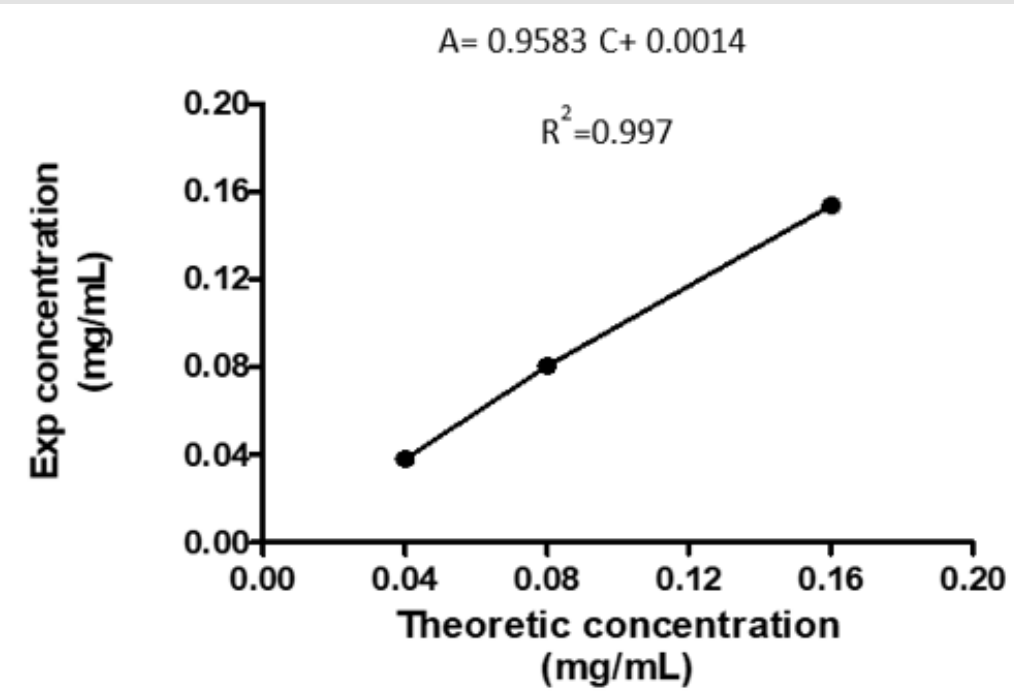

Figure 2: Recovery curve of Cexp vs C theoretic obtained by modified Lowry.

Table 2: Analysis of intermediate precision and accuracy in the evaluated range of bovine serum albumin by two analysts.

\begin{tabular}{|c|c|c|c|c|c|c|c|c|c|}
\hline \multicolumn{10}{|c|}{ Analyst-1 } \\
\hline \multirow{2}{*}{$\begin{array}{l}\text { C.Theor } \\
(\mathrm{mg} / \mathrm{mL})\end{array}$} & Assay 1 & Assay 2 & Assay 3 & C.M. Glob & SD & RSD (\%) & R (\%) & $t_{\text {teo }}$ & $\mathbf{t}_{\text {calc }}$ \\
\hline & \multicolumn{9}{|c|}{ C.M (mg/mL) } \\
\hline 0,02 & 0,021 & 0,023 & 0,019 & 0,021 & 0,002 & 9,52 & 106 & 4,3 & 1,51 \\
\hline 0,06 & 0,064 & 0,062 & 0,060 & 0,062 & 0,002 & 3,23 & 103 & & 1,15 \\
\hline 0,1 & 0,107 & 0,101 & 0,103 & 0,104 & 0,003 & 2,91 & 104 & & 1,8 \\
\hline 0,14 & 0,136 & 0,143 & 0,139 & 0,139 & 0,004 & 2,86 & 100 & & 0,33 \\
\hline 0,18 & 0,177 & 0,178 & 0,180 & 0,178 & 0,001 & 0,56 & 99 & & 1,89 \\
\hline \multicolumn{10}{|c|}{ Analyst-2 } \\
\hline \multirow{2}{*}{$\begin{array}{l}\text { C.Theor } \\
(\mathrm{mg} / \mathrm{mL})\end{array}$} & Assay 1 & Assay 2 & Assay 3 & C.M. Glob & SD & RSD (\%) & R (\%) & $t_{\text {teo }}$ & $\mathbf{t}_{\text {calc }}$ \\
\hline & \multicolumn{9}{|c|}{ C.M (mg/mL) } \\
\hline 0,02 & 0,018 & 0,020 & 0,019 & 0,019 & 0,001 & 5,880 & 94 & 4,3 & 3,024 \\
\hline 0,06 & 0,062 & 0,060 & 0,061 & 0,061 & 0,001 & 1,640 & 102 & & 1,732 \\
\hline 0,1 & 0,100 & 0,101 & 0,102 & 0,101 & 0,001 & 0,990 & 101 & & 1,732 \\
\hline 0,14 & 0,139 & 0,137 & 0,142 & 0,140 & 0,003 & 2,140 & 100 & & 0,459 \\
\hline 0,18 & 0,181 & 0,182 & 0,176 & 0,180 & 0,003 & 1,667 & 100 & & 0,18 \\
\hline
\end{tabular}

Table 3: Values of percentage recovery and RSD for the method of addition of bovine serum albumin to the sample of R.junceus scorpion venom $(n=3)$.

\begin{tabular}{|c|c|c|c|c|c|c|c|c|}
\hline Interval & C.Theor & C.Exp & R (\%) & Mean of $\% \mathrm{R}$ & SD of $\% R$ & RSD of $\% \mathrm{R}$ & tteo & tcalc \\
\hline & & 0,039 & 98 & & & & & \\
\hline \multirow[t]{3}{*}{ LR } & 0,04 & 0,041 & 110 & 100 & 3 & 3 & 4,3 & 0,22 \\
\hline & & 0,040 & 90 & & & & & \\
\hline & & 0,081 & 101 & & & & & \\
\hline \multirow[t]{3}{*}{ MR } & 0,08 & 0,088 & 110 & 106 & 5 & 4 & & 2,4 \\
\hline & & 0,086 & 108 & & & & & \\
\hline & & 0,147 & 92 & & & & & \\
\hline \multirow[t]{2}{*}{ HR } & 0,16 & 0,149 & 93 & 94 & 3 & 3 & & 3,4 \\
\hline & & 0,156 & 98 & & & & & \\
\hline
\end{tabular}

Interval: range, LR: Low Range, MR: Medium Range, HR: High Ranges, C.Theor: Theoretic Concentration, C.Exp: Experimental Concentration, SD: Standard Deviation, RSD: Relative Standard Deviation, R: Recovery, $\mathbf{t}_{\text {teo }}:$ Theoretical Student $\mathbf{t}$, $\mathbf{t}_{\text {calc }}:$ Calculated Student t. 
The Cochran G test demonstrated the equivalence of the three concentrations, and it was evidenced that the concentration factor did not influence the variability of the results ( $G \exp <G$ tab). The value of $\mathrm{G}$ exp was 0.556 and according to the applied design, the tabulated $\mathrm{G}$ value for $\alpha=0.05$, three concentration levels $(\mathrm{k}=3)$ and three replicates $(\mathrm{n}=3)$ was 0.778 .
In the repeatability experiments, high concordance between the experimental results was observed when the method was performed under the same operating conditions, since the acceptance criteria for this test (RSD $\leq 5 \%$ ) were accomplished (Table 4). Results of intra-day precision tests (repeatability test) for determination of total protein of R,junceus scorpion venom in standard solutions.

Table 4: Results of intra-day precision tests (repeatability test) for determination of total protein of $\mathbf{R}$. junceus scorpion venom in standard solutions.

\begin{tabular}{|c|c|c|c|c|}
\hline Interval & C.Exp $(\mathrm{mg} / \mathrm{mL})$ & C.Mean $(\mathrm{mg} / \mathrm{mL})$ & SD & RSD (\%) \\
\hline \multirow{6}{*}{ LR } & 0,036 & \multirow{6}{*}{0,036} & \multirow{6}{*}{0,002} & \multirow{6}{*}{4,272} \\
\hline & 0,034 & & & \\
\hline & 0,035 & & & \\
\hline & 0,034 & & & \\
\hline & 0,038 & & & \\
\hline & 0,036 & & & \\
\hline \multirow{6}{*}{ MR } & 0,080 & \multirow{6}{*}{0,082} & \multirow{6}{*}{0,003} & \multirow{6}{*}{4,194} \\
\hline & 0,082 & & & \\
\hline & 0,080 & & & \\
\hline & 0,088 & & & \\
\hline & 0,082 & & & \\
\hline & 0,078 & & & \\
\hline \multirow{6}{*}{$\mathrm{HR}$} & 0,142 & \multirow{6}{*}{0,151} & \multirow{6}{*}{0,005} & \multirow{6}{*}{3,093} \\
\hline & 0,148 & & & \\
\hline & 0,154 & & & \\
\hline & 0,152 & & & \\
\hline & 0,153 & & & \\
\hline & 0,154 & & & \\
\hline
\end{tabular}

Interval: Range, LR: Low Range, MR: Medium Range, HR: High Ranges, C.Exp: Experimental Concentration, C.Mean: Mean Concentration, SD: Standard Deviation, RSD: Relative Standard Deviation.

The results in the intermediate precision studies are shown in Table 5. The concentration values obtained by two analysts on three different days, showed RSD below of $10 \%$ established as a maximum limit, which demonstrates compliance with the acceptance criteria in the entire range studied for R. junceus scorpion venom [10].

Table 5: Results of inter-day precision tests (intermediate precision test) for determination of total protein of $R$. junceus scorpion venom in standard solutions.

\begin{tabular}{|c|c|c|c|c|c|c|c|}
\hline & \multirow{2}{*}{ Interval } & \multicolumn{3}{|c|}{ C.Exp (mg/mL) } & \multirow{2}{*}{$\begin{array}{c}\text { C.Mean (mg/ } \\
\text { mL) }\end{array}$} & \multirow{2}{*}{$\mathrm{SD}(\mathrm{mg} / \mathrm{mL})$} & \multirow{2}{*}{ RSD (\%) } \\
\hline & & Day 1 & Day 2 & Day 3 & & & \\
\hline \multirow{3}{*}{ Analyst- 1} & LR & 0,043 & 0,048 & 0,051 & 0,047 & 0,004 & 8,756 \\
\hline & MR & 0,081 & 0,076 & 0,085 & 0,081 & 0,004 & 5,352 \\
\hline & HR & 0,135 & 0,146 & 0,151 & 0,144 & 0,008 & 5,759 \\
\hline \multirow{3}{*}{ Analyst-2 } & LR & 0,034 & 0,040 & 0,039 & 0,038 & 0,003 & 8,905 \\
\hline & MR & 0,072 & 0,072 & 0,084 & 0,076 & 0,007 & 8,964 \\
\hline & HR & 0,149 & 0,152 & 0,174 & 0,158 & 0,014 & 8,621 \\
\hline
\end{tabular}

Interval: Range, LR: Low Range, MR: Medium Range, HR: High Ranges, C.Exp: Experimental Concentration, C.Mean: Mean Concentration, SD: Standard Deviation, RSD: Relative Standard Deviation. 
The Lowry technique seems to be the bestmethodin determining the protein concentration of hen egg, because Biuret assay is not much sensitive and Bradford can be inhibited by the presence of many compounds [11]. For that reason, our entrepreneurial group validated the Lowry technique for determination of total protein in R.junceus scorpion venom and proposes the implementation of the Lowry method modified to microplate in our quality department. Besides, the present study could be very useful for another group that work with scorpion venom or for other studies that need to validate one analytical method for changing of equipment to measure the concentration of one analyte [12-14].

\section{Conclusion}

The method of Lowry modified to microplates is specific, linear, precise and exact, so it is considered valid for the quantification of proteins present in R. junceus scorpion venom.

\section{Acknowledgment}

The authors are grateful to colleagues from quality department of LABIOFAM. Besides, authors want to acknowledge particularly the assistance of the personnel from the scorpion Bioterium especially to personal of scorpion bioterium facilities LABIOFAMCienfuegos.

\section{Funding}

This research did not receive any specific grant from funding agencies in the public, commercial, or not-for-profit sectors.

\section{References}

1. Rodríguez de la Vega R, Possani L (2013) Scorpion venom peptides. In: Kastin A (Ed). Handbook of Biologically Active Peptides. $2^{\text {nd }}$ edn Elsevier pp. 423-429.

2. Ortiz E, Gurrola G, Schwartz E, Possani L (2015) Scorpion venom components as potential candidates for drug development. Toxicon 93 : 125-135.

ISSN: 2574-1241

DOI: $10.26717 /$ BJSTR.2020.28.004655

Arianna Yglesias-Rivera. Biomed J Sci \& Tech Res

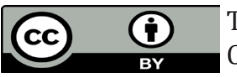

This work is licensed under Creative Commons Attribution 4.0 License

Submission Link: https://biomedres.us/submit-manuscript.php
3. Moradi M, Solgi R, Vazirianzadeh B, Tanzadehpanah H, Saidijam M (2018) Scorpion venom and its components as new pharmaceutical approach to cancer treatment, a systematic review. IJPSR 9(7): 2604-2615.

4. Yglesias-Rivera A, Sánchez-Mamposo AM, Díaz-García A, RodríguezSánchez H (2020) Synergism of the combination of Rhopalurus junceus scorpion venom with conventional cytostatics in the CT26 tumor cell line. Asian J Biomed Pharmaceut Sci 10(69): 1-9.

5. Díaz-García A, Morier-Díaz L, Frión-Herrera Y, Rodríguez-Sánchez H, Caballero-Lorenzo Y, et al. (2013) In vitro anticancer effect of venom from Cuban scorpion Rhopalurus junceus against a panel of human cancer cell lines. J Venom Res 4: 5-12.

6. Díaz-García A, Ruiz-Fuentes JL, Rodríguez-Sánchez H, Fraga-Castro JA (2017) Rhopalurus junceus scorpion venom induces apoptosis in the triple negative human breast cancer cell line MDA-MB-231. J Venom Res 8: 9-13.

7. Booth B, Arnold ME, DeSilva B, Amaravadi L, Dudal S, et al. (2015) Workshop Report: Crystal City V Center for State Control of the Quality of Medicines: Validation of Analytical Methods. Regulation No.41, 2013: $3-18$.

8. Lowry OH, Rosebrough NJ, Farr AL, Randall RJ (1951) Protein measurement with the Folin phenol reagent. J Biol Chem 193: 265-275.

9. Herrera Y, Heras Ny Cardoso D (1999) Adaptation to microplates and validation of the Lowry technique. Vacci Monitor 3: 7-11.

10. Miyares M, González J, Torres D, Muñoz L, Pestana Y, et al. (2013) Validation of the technique of determination of total proteins by microcoomassie method to double wave longitude for the sample of Finished Product of hepatitis C core antigen. Vacci Monitor 22(2): 14-18.

11. Martina V and Vojtech K (2015) A comparison of Biuret, Lowry, and Bradford methods for measuring the egg's proteins. MENDELNET pp. 394-398.

12. ICH Q2 (R1) (2005) Validation of analytical procedures: Text and Methodology. London.

13. Burcu Okutucu, Ayșşe Dinçer, Omer Habib, Figen Zihnioglu (2007) Comparison of five methods for determination of total plasma protein concentration. J Biochem Biophys Methods 70(5): 709-711.

14. Farmacopea de los Estados Unidos de América. Formulario Nacional. Estados Unidos (2017) Validación de procedimientos farmacopeicos. Vol 1: 967.

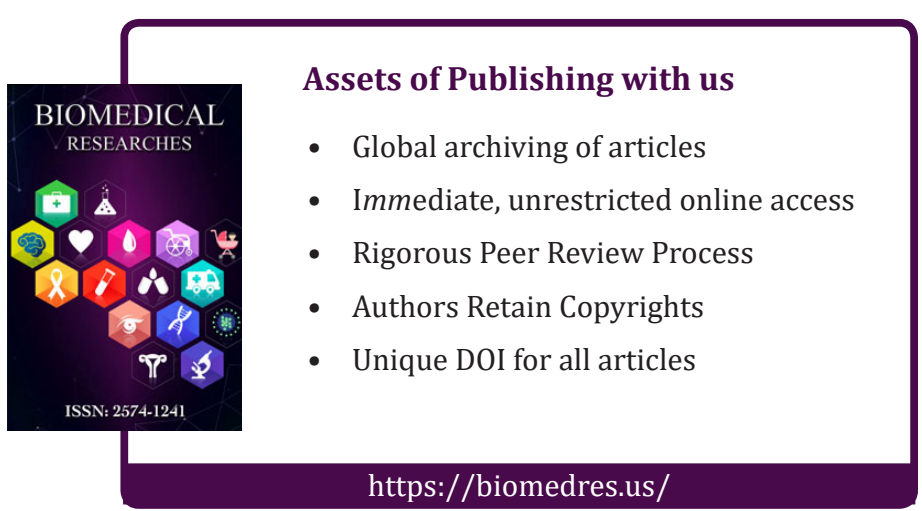

